\title{
Using Karaoke Videos to Teach Japanese Vocabulary to Taiwanese University Students
}

\author{
Abolfazl Shirban Sasi \\ TransWorld University, Douliu, Taiwan \\ Toshinari Haga \\ TransWorld University, Douliu, Taiwan
}

\begin{abstract}
This paper reports the usage of Japanese karaoke films in order to enhance learning Japanese vocabulary among students in a university in Taiwan. A pretest-posttest control-group design was implemented in which the treatment students ( 55 girls and 48 boys) were given Japanese vocabulary lessons via listening to and watching two karaoke films, while the control group (62 girls and 47 boys) received their Japanese vocabulary lessons through only listening to the same songs $(\mathrm{N}=212, P \leq 0.05)$. The treatment lasted for six consecutive regular general Japanese classes in which the last 20 minutes of the session was allocated to this experiment. The statistical independent samples T-tests used for each of the three comparisons in this study revealed a significant higher gain scores for the girls treatment group, while the boys treatment and control, as well as the general (all) students treatment and control groups did not show any significant difference. Given the ever-growing usage of karaoke in many countries such as Taiwan, the authors believe that addressing the possible and potential capabilities of such a favorable activity, particularly among the youth, can prove effective and helpful in teaching/learning Japanese and other languages.
\end{abstract}

Index Terms - karaoke, Japanese, music, vocabulary

\section{INTRODUCTION}

There have been numerous studies concerning the effects of various types of music on language learning. Whether music is used as a means of relaxation in language learning atmospheres, or else, as a means for introducing different features of a particular language such as its vocabulary, there are controversial debates as to its usefulness or even disadvantage (for example, as a distraction from the main focus of the language learners). In Taiwan, there are two obvious phenomena which made this study worth conducting: 1) Japanese is the second most popular foreign language to be learnt; and 2) people love karaoke. As Shanley (1998) postulates, outside Japan, the largest number of karaoke clubs, more commonly referred to as KTVs, can be found in Taiwan. Karaoke combines two Japanese words: kara, short for karappo, which means empty; and oke, part of okestura, meaning orchestra. To the best knowledge of the authors, there has not been any study done to investigate the probable effects usage of karaoke in a class can have on learning a language, in this case the Japanese language. Thus, the current study tries to address this issue in case of university students in Taiwan.

\section{REVIEW OF LITERATURE}

The use of music in the life of mankind dates back to prehistory. As Langer (1957) describes, "Man discovered how to a change a pitch to make some notes stand out. Being more valuable than the drum, voices soon made patterns, and the long wandering melodies of primitive song became an integral part of communal celebration" (p. 130). By the passage of time, these vocalizations started to symbolize representations of things outside of the context of the ritual itself. Likewise, Yule (1985) has a similar stand when he talks about "bow-wow" and "yo-heave-ho" theories of language origins. Similarly, Gombrich (1972), remarks that there are astronomical numbers of stimuli that we encounter every moment. He further states, "Whatever can be coded in symbols can also be retrieved and recalled with relative ease" (p.15). In tandem with these notions, we can observe that music has an unquestionable role in our daily life. According to Wallace (1994), using songs with a repeated and simple pattern can facilitate precise text recall in the native language. In some cases, music has been an integrated part of the language teaching method as well. For instance, according to Larsen-Freeman and Anderson (2011), there are two concerts used as the components of the receptive phase of the lessons in Desuggestopedia. In the first part, the teacher starts reading a slow, dramatic piece which is synchronized in intonation with the music (preferably a Classical); then, in the second part, the language learners are asked to put their scripts aside, and just listen to the teacher who reads the dialogs at a normal speed while the music (a pre-Classical or Baroque) is played as the background.

The reason karaoke might help language learners learn more efficiently, the authors hypothesize, may be due to effects explained in dual coding theory by Paivio (1971). Several neurobiological evidence support the notions in this theory that the human brain maintains functionally independent verbal and nonverbal representational and processing 
systems. In other words, different areas in the brain are specialized for processing information verbally and nonverbally. According to Paivio (1971), affective and emotional reactions would be expected to accompany other nonverbal cognitive reactions such as imagery. In more technical terms, dual coding theory states that mental representation is organized into two separate coding systems - one specialized for language and the other for nonverbal objects and events. The basic units for verbal representations are called 'logogens' and the basic units for nonverbal representations are called 'imagens' (Paivio \& Begg, 1981, p.247). The verbal system is ordered sequentially whereas the nonverbal system is ordered non-sequentially. For example, morphemes occur in sequential patterns that adhere to associative constraints; whereas, nonverbal representations often appear in compound images and represent episodes holistically. Thus, verbally and pictorially presented material should be easier to recall than information presented in only one modality because the two representations provide redundant retrieval routes. It has also been suggested that pictures increase motivation and attention to the material, make the material more concrete and comprehensible, and serve to organize verbal data. Likewise, advocates of visual-literacy education claim that a more visually oriented instruction would also lead to broader cognitive settlement; because this provides the students with more mental tools with which to perceive the world around them (Arnheim, 1974, 1997; Dondis, 1973; Dwyer, 1978; Gombrich, 1982; Messaris, 1994).

Music can have a positive influence on both verbal and non-verbal performance in providing a boost in psychophysiological incitement and mood (Cassidy \& MacDonald, 2007; Jones, West, \& Estell, 2006; Schellenberg, 2006). Music is frequently considered to be a good help to enhance memory. For instance, Legg's (2009) study divided early teenager French learning students into music and non-music groups. The non-music group used traditional teaching strategies which involved listening and repeating French words and phrases, and the learning materials for the music group were prepared in sung novel melodies. Consequently, students in the music group had significantly higher posttest memory for the L2 materials compared to the non-music group. Similarly, Thiessen and Saffran (2009), observed that infants learned lyrics better when they were paired with a melody compared to when they were just uttered. Also, Brett (2001) reported a study in which language learners were required not only to attend to language in various audiovisual presentations, but also to simultaneously perform an interactive task. He found that students exposed to video and subtitles performed best on written summaries. There are also other cognitive neurological studies which suggest that music has significant impact on linguistic memory and consequently, improvement of language tasks (Jentschke, Koelsch, \& Friederici, 2005; Patel, 2008; Sammler et al., 2010). Nonetheless, on the other end of the continuum, there are claims that disruptive music makes excess demands on the limited processing capability of cognitive systems, and thus, reducing available resources for other parallel tasks to perform adequately (Kämpfe, Sedlmeier, \& Renkewitz, 2010; Schellenberg, 2012). In other words, music might as well have negative effects on language learning.

\section{MATERIAL AND METHOD}

\section{Introduction}

The purpose of the data collected in this pre-test post-test control-group study was to explore the effects of using Japanese karaoke in order to enhance teaching Japanese vocabulary to Taiwanese university students who are learning Japanese as a second foreign language.

\section{Design of the Study}

The pre-test post-test control-group design of the current study has the following characteristic as stated by Creswell (2003, p170):

- The experimental group A and the control group B were randomly assigned.

- Both groups took a pre-test and post-test.

- The experimental group received the main treatment (Japanese karaoke).

- The control group received a different treatment (Japanese songs).

\section{Participants and procedure}

Six classes of undergraduate students in TransWorld University, Taiwan participated in this study. These students were mostly from College of Design, and College of Hospitality and Tourism. They took "General Japanese" as the second foreign language. Most of the students were Taiwanese except for eight Malaysian Chinese students. These six classes were randomly assigned to two groups of three classes each. The treatment students (55 girls and 48 boys) were given Japanese vocabulary lessons through listening to and watching two karaoke films (Song-1: Secret Base; Song-2: Snowpack; Appendix A), while the control group (62 girls and 47 boys) received their Japanese vocabulary lessons through only listening to the same songs. Prior to the experiment, all the participants were given a handout of the full texts of each song in Japanese with Chinese translation. The time allocated to each activity for both groups was about 20 minutes at the end of each regular class. The study was conducted in six consecutive weeks (two for the tests, and four for the lessons). Only the students who were present in both pre-test and post-test have been accounted for in this experiment.

\section{Data Collection}

A 40-item multiple-choice Japanese vocabulary test was designed by the authors. In this test, for each Japanese word, three choices were given in Chinese (Appendix B). Although all the words were introduced and taught during the sessions of karaoke and the audio songs for both treatment and control groups, precautions were taken so that the words 
be as difficult as possible in order to maintain the discriminating power of the test items. This test was administered to both control and treatment groups exactly one week prior and one week after the experiment. The Only correct answers were counted, so unanswered test items or wrong answers were disregarded.

\section{Research Questions and Hypotheses}

Based on the main objective of this study which was to examine any probable effects of the usage of Japanese karaoke in enhancing learning Japanese vocabulary, the following research questions, and null hypotheses were made. (For the sake of brevity, the three comparisons are shown together).

1- Is there any significant difference in Japanese vocabulary gain score between the students who were taught the vocabulary through Japanese karaoke, and those who were taught the vocabulary with audio music alone (in boys, girls, and all students)?

$\mathrm{H}_{0} 1$ - There is no significant difference in Japanese vocabulary gain score between the students who were taught the vocabulary through the Japanese karaoke, and those who were taught the vocabulary with audio music alone (in boys, girls, and all students).

\section{RESUlTS}

Because the statistical test used in this research was an independent samples t-test, the three assumptions of independence of observations, scores distribution normality, and homogeneity of the variances had to be met. As mentioned before, the treatment and the control groups were randomly assigned. Moreover, the two groups had no idea as to what teaching material was used for the other one. Therefore, the independence of observations has been maintained in this study.

Then as for the normality of the distribution of the scores in the population, we must see the descriptive statistics results including the K-S test for each of the three comparisons done in this study as summarized in TABLE 1.

TABLE 1:

DESCRIPTIVE STATISTICS FOR THE THREE COMPARISONS

\begin{tabular}{|c|c|c|c|c|}
\hline & Boys & & Statistic & Std. Error \\
\hline \multirow[t]{8}{*}{ Gain scores } & Treatment & Mean & 5.7708 & 1.99606 \\
\hline & & Median & 5.0000 & \\
\hline & & Skewness & .204 & .343 \\
\hline & & Kurtosis & .182 & .674 \\
\hline & $\overline{\text { Control }}$ & Mean & 6.1489 & 1.86946 \\
\hline & & Median & 7.0000 & \\
\hline & & Skewness & -.063 & .347 \\
\hline & & Kurtosis & -.603 & .681 \\
\hline & Girls & & Statistic & Std. Error \\
\hline \multirow[t]{9}{*}{$\overline{\text { Gain scores }}$} & Treatment & Mean & 9.3091 & 1.60741 \\
\hline & & Median & 10.0000 & \\
\hline & & Skewness & -.403 & .322 \\
\hline & & Kurtosis & -.352 & .634 \\
\hline & $\overline{\text { Control }}$ & Mean & 5.0806 & 1.31003 \\
\hline & & Median & 5.0000 & \\
\hline & & Skewness & -.183 & .304 \\
\hline & & Kurtosis & -.397 & .599 \\
\hline & All Students & & Statistic & Std. Error \\
\hline \multirow[t]{8}{*}{ Gain scores } & Treatment & Mean & 7.6602 & 1.27142 \\
\hline & & Median & 7.0000 & \\
\hline & & Skewness & -.113 & .238 \\
\hline & & Kurtosis & -.175 & .472 \\
\hline & Control & Mean & 5.5413 & 1.09353 \\
\hline & & Median & 6.0000 & \\
\hline & & Skewness & -.082 & .231 \\
\hline & & Kurtosis & -.439 & .459 \\
\hline
\end{tabular}

TABLE 1 shows that in each comparison, the mean is very close to the median in both treatment and control groups. We can also look at the skewness and kurtosis statistics. Here, we can see that all the skewness and kurtosis values are small relative to the standard errors. Thus, the skewness and kurtosis of the distributions are not problematic here. Furthermore, the K-S test of normality for each comparison gives us a significant $p$ value of .200 suggesting that the distributions of the gain scores are normal.

Then in order to determine whether the assumption of the homogeneity of the variances has been met, we should investigate the results of the independent samples t-test for each comparison as shown in TABLE 2. 
TABLE 2:

INDEPENDENT SAMPLES TEST FOR THE GAIN SCORES (THREE COMPARISONS)

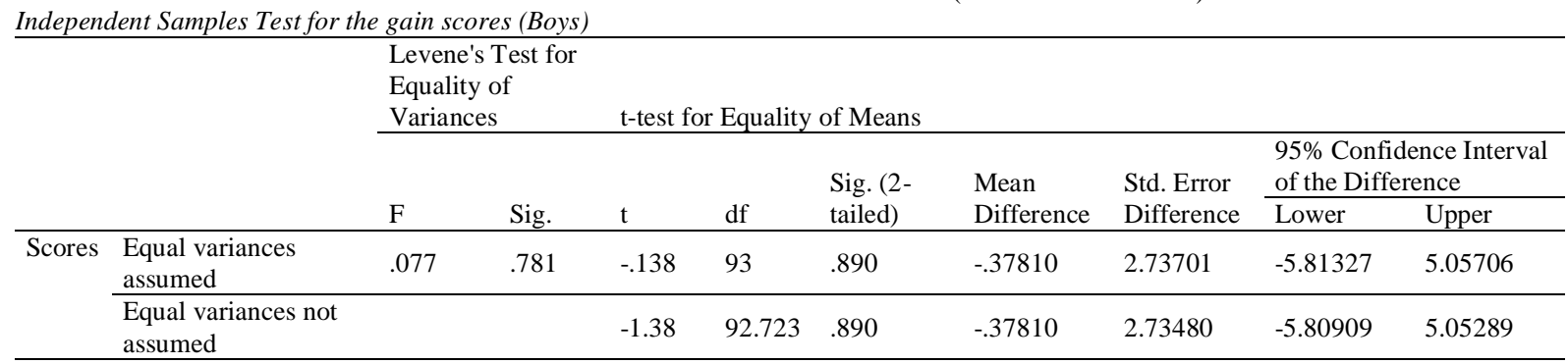

Independent Samples Test for the gain scores (Girls)

Levene's Test for

Equality of

Variances t-test for Equality of Means

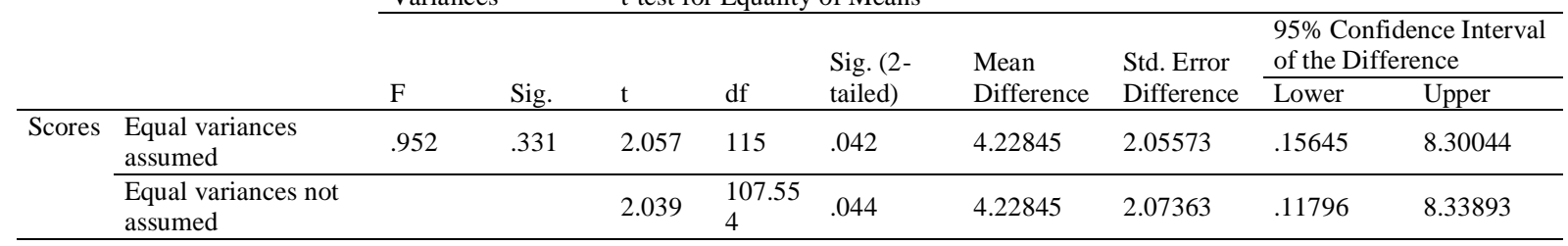

Independent Samples Test for the gain scores (All Students)

\begin{tabular}{|c|c|c|c|c|c|c|c|c|c|c|}
\hline & (2) & \multicolumn{2}{|c|}{$\begin{array}{l}\text { Levene's Test for } \\
\text { Equality of } \\
\text { Variances }\end{array}$} & \multicolumn{5}{|c|}{ t-test for Equality of Means } & \multirow{2}{*}{\multicolumn{2}{|c|}{$\begin{array}{l}95 \% \text { Confidence Interval } \\
\text { of the Difference }\end{array}$}} \\
\hline & & \multirow[b]{2}{*}{$\mathrm{F}$} & \multirow[b]{2}{*}{ Sig. } & \multirow[b]{2}{*}{$\mathrm{t}$} & \multirow[b]{2}{*}{ df } & \multirow{2}{*}{$\begin{array}{l}\text { Sig. }(2- \\
\text { tailed) }\end{array}$} & \multirow{2}{*}{$\begin{array}{l}\text { Mean } \\
\text { Difference }\end{array}$} & \multirow{2}{*}{$\begin{array}{l}\text { Std. Error } \\
\text { Difference }\end{array}$} & & \\
\hline & & & & & & & & & Lower & Upper \\
\hline \multirow[t]{2}{*}{ Scores } & $\begin{array}{l}\text { Equal variances } \\
\text { assumed }\end{array}$ & 1.308 & .254 & 1.268 & 210 & .206 & 2.11891 & 1.67120 & -1.17557 & 5.41339 \\
\hline & $\begin{array}{l}\text { Equal variances not } \\
\text { assumed }\end{array}$ & & & 1.264 & $\begin{array}{l}203.53 \\
4\end{array}$ & .208 & 2.11891 & 1.67700 & -1.18761 & 5.42543 \\
\hline
\end{tabular}

In TABLE 2, the significance value of the Levene's Test for boys, girls, and all students are $.781, .331$, and .254 respectively, which are larger than .05 . This means that the assumption of homogeneity of the variances of the scores for the population in case of each of these three comparisons has been met. Thus, we should use the first line in the table, which refers to "equal variances assumed". Therefore, in the current tests we are dealing with the following results for each of the compared groups as follows:

Boys: $\mathrm{t}(95)=-.138, p=.890$

As the $p=.890$ is larger than the required cut-off value of .05 , the null hypothesis is not rejected and, thus, we can conclude that there is not a statistically significant difference in the Japanese vocabulary gain score between the control and treatment groups.

All students: $\mathrm{t}(212)=1.268, p=.206$

As the $p=.206$ is larger than the required cut-off value of .05 , the null hypothesis is not rejected and, thus, we can conclude that there is not a statistically significant difference in the Japanese vocabulary gain score between the control and treatment groups of all students together.

Girls: $\mathrm{t}(117)=2.057, p=.042$

As the $p=.042$ is less than the required cut-off value of .05 , the null hypothesis is rejected and we can conclude that there is a statistically significant difference in the Japanese vocabulary gain score between the control and treatment groups. Also, as for the direction of the difference, we can see in TABLE 3 that the mean Japanese vocabulary gain score of 9.30 for the treatment group is larger than the mean Japanese vocabulary gain score of 5.08 for the control group. Thus, we can conclude that, as the alternative directional hypothesis conveys, those students who were taught the Japanese words through karaoke have higher Japanese vocabulary gain score than those who did not use the Japanese karaoke.

TABLE 3:

\begin{tabular}{llllll}
\multicolumn{6}{c}{ GrouP STATISTICS. (GIRLS) } \\
\hline Gain & Group & $\mathrm{N}$ & Mean & Std. Deviation & Std. Error Mean \\
scores & Treat. & 55 & 9.3091 & 11.92084 & 1.60741 \\
& Control & 62 & 5.0806 & 10.31519 & 1.31003 \\
\hline
\end{tabular}

As the hypothesis has been explored, we need to measure the effect size statistics which provides us with an indication of the magnitude of the differences between the two groups. A common way to do this is to calculate the eta 
squared. Since SPSS does not provide eta squared values for t-tests, we should do the calculations on our own using the information provided in the output. The procedure for calculating and interpreting eta squared is by using the following formula as stated by Pallant (2005):

$$
\begin{aligned}
& \text { Eta Squared }=\frac{t^{2}}{t^{2}+(N-1)} \\
& \text { Eta Squared }=\frac{(2.057) \times(2.057)}{(2.057) \times(2.057)+115}=0.035
\end{aligned}
$$

According to Cohen (1988), the guidelines for interpreting this value are: $.01=$ small effect, .06=moderate effect, .14=large effect. Thus, we would claim that the effect size of .035 for this test is rather a small effect. Subsequently, if we multiply this value by 100 , we can have the percentage, meaning that approximately 3.5 percent of the variance in Japanese vocabulary gain score is explained by the two different teaching treatments.

\section{DISCUSSION}

In this article, the authors have experimented whether or not using karaoke videos can enhance learning Japanese vocabulary. The results showed that among the students, only girls seemed to have benefited from these videos, as the other two groups; that is, boys and all students together did not show a significant difference. If we merely consider girls, then these current findings support the claims and findings of Cassidy \& MacDonald (2007), Jentschke, Koelsch, \& Friederici (2005), Jones, West, \& Estell (2006), Patel (2008), Sammler et al. (2010), and Schellenberg (2006). Moreover, this improvement of learning, the authors postulate, may well be due to dual coding theory posed by Paivio (1971) and the other advocates of this theory in stating that verbally and pictorially presented material must be easier to recall than information presented in only one modality. Nonetheless, the authors acknowledge that the results of this study are not conclusive because of limitations such as the small sample size, short duration of the project, and the types of karaoke movies selected for this experiment. For instance, there was no way in this study to consider students' personal preferences as to what type of karaoke is preferred by the participants. In this view, perhaps cartoons are more favored by the girls, and that is why they scored higher because one of the two karaoke videos (the longer one) was a Japanese cartoon. On the other hand, it might be the case that despite all arguments in favor of positive effects of music (and perhaps, karaoke in our case), inappropriate music may impede language students from learning, as assumed by Kämpfe, Sedlmeier, \& Renkewitz (2010), and Schellenberg (2012).

\section{CONCLUSION}

The current study focused on the effects of using karaoke videos on learning Japanese vocabulary by the Taiwanese university students. The results revealed a slightly significant difference between girls and boys. That is, watching and listening to Japanese karaoke would help girls learn Japanese vocabulary better than those who only listened to the songs. Moreover, no significant difference was observed in boys, or among all students together. Considering the procedure adopted, and the results obtained in this study, the authors recommend the following for further investigation in future:

- Studying the effects of using karaoke in learning/teaching languages other than Japanese;

- Conducting similar research with longer durations of treatment;

- Performing similar research with different types of participants, and bigger sample size;

- Using various genres of karaoke videos and critically investigating their effects on learning a particular language;

- Studying how trying to actively singing in the target language in karaoke sessions may possibly help language learners.

APPENDIX A. JAPANESE LYRICS

Secret Base 〜 君がくれたもの〜

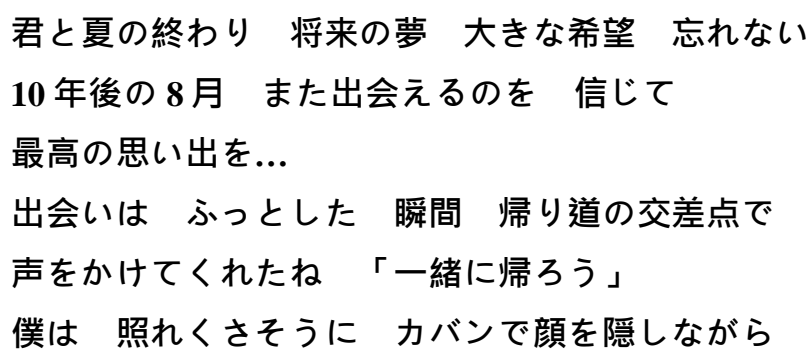


本当は とても とても 嬉しかったよ

ああ 花火が夜空 きれいに咲いて ちょっとセッナク

ああ 風が時間とともに 流れる

嬉しくって 楽しくって 冒険もいろいろしたね

二人の 秘密の 基地の中

君と夏の終わり 将来の夢 大きな希望 忘れない

10 年後の 8 月 また出会えるのを 信じて

君が最後まで 心から「ありがとう」叫んでたこと知ってたよ

涙をこらえて 笑顔でさようなら せつないよね

最高の思い出を...

ああ 夏休みも あと少しで 終わっちゃうから

ああ 太陽と月 仲良くして

悲しくって 寂しくって 喧嘩も いろいろしたね

二人の 秘密の 基地の中

君が最後まで 心から「ありがとう」叫んでたこと 知ってたよ

涙をこらえて 笑顔でさようなら せつないよね

最高の思い出を...

突然の 転校で どうしようもなく

手紙 書くよ 電話もするよ 忘れないでね 僕のことを

いつまでも 二人の 基地の中

君と夏の終わり ずっと話して タ日を見てから星を眺め

君の㚘をを流れた淚はずっと忘れない

君が最後まで 大きく手を振ってくれたこときと忘れない

だから こうして 夢の中で ずっと永遠に...

君と夏の終わり 将来の夢 大きな希望 忘れない

10 年後の 8 月 また出会えるのを 信じて

君が最後まで 心から「ありがとう」叫んでたこと知ってたよ

涙をこらえて 笑顔でさようなら せつないよね

最高の思い出を...

最高の思い出を...

$* * * * * * * * * * * * * * * * * * * * *$

なごり雪（ Nagoriyuki/Snowpack)

汽車を待つ君の横で僕は

時計を気にしてる

季節はずれの雪が降ってる

「東京で見る雪はこれが最後ね」と

さみしそうに君はつぶやく

なごり雪も降るときを知り

ふざけすぎた季節のあとで 
今春が来て 君はきれいになった

去年よりずっときれいになった

動き始めた汽車の空に

顔をつけて

君は何か言おうとしている

君の口びるが「さようなら」と動くことが

こわくて下をむいてた

時が行けば 幼ない君も

大人になると気づかないまま

今春が来て 君はきれいになった

去年よりずっときれいになった

君が去ったホームにのこり

落ちてはとける雪を見ていた

今 春が来て 君はきれいになった

去年よりずっときれいになった

去年よりずっときれいになった

去年よりずっときれいになった

APPEndix B. The JAPANESE Vocabulary TeST

\begin{tabular}{|c|c|c|c|}
\hline \multicolumn{4}{|c|}{ 學制：・日四技 口日二技 ロ日二專 口夜四技 口夜二技 口夜二專(請勾選) } \\
\hline 學年/學期 & 106 學年/第二學期 & 學生學號 & \\
\hline 學生姓名 & & 性別 & 男 \\
\hline
\end{tabular}

1.きみ

2.なつ

3. おわり

4.しょうらい

5. ゆめ

6. きぼう

7.わすれない

8.しんじて

7. さいこう

10. おもいで

11.いつしょに

12. とても

13. うれしくつて

14.たのしくって

15.いろいろ

16.ふたり

17.ひみつ

18.しつてたよ

19. かなしくつて

20. さびしくって

21.きしゃ

22. まつ

23. よ己

24. さいご a. 我們

a. 春天

a. 開始

a. 過去

a. 夢想

a. 希望

a. 不會害怕

a. 知道

a. 最新的

a. 回億

a. 各自

a. 一點點

a. 開心

a. 害怕

a. 年幼的

a. 一個人

a. 故事

a. 我知道

a. 殘雪

a. 熱閙

a. 計程車

a. 看到

a. 旁邊

a. 最初

b. 你

c. 他

b. 夏天

b. 中途

c. 秋天

b. 現在

c. 結束

b. 現實

c. 未来

b. 想像

c. 理想

b. 不會注意

c. 美麗

b. 懷疑

c. 不會忘記

b. 最好美的

c. 相信

b. 降落

b. 你們

c. 最近的

b. 非常

b. 傷感

b. 悲痛

b. 一種

b. 倆個人

c. 飛逝

c. 一起

c. 害怕地

c. 寂寞

c. 歡樂

c. 各式各樣

b. 秘密

b. 他走了

b. 悲痛

b. 開心

b. 火車

b. 說

b. 上面

b. 途中

c. 大家

c. 俗語

c. 你看到了

c. 美麗

c. 寂寞

c. 飛機

c. 等

c. 裡面

c. 最後 


$\begin{array}{llll}\text { 25. さみしそう } & \text { a. 開心 } & \text { b. 歡樂 } & \text { c. 傷感 } \\ \text { 26. つぶやく } & \text { a. 喃喃説 } & \text { b. 緩緩開走 } & \text { c. 徐徐吹來 } \\ \text { 27. なごりゆき } & \text { a. 残雪 } & \text { b. 季節 } & \text { c. 嘴唇 } \\ \text { 28. ふざけ } & \text { a. 擾嚷 } & \text { b. 害怕的 } & \text { c. 年幼的 } \\ \text { 29. きせつ } & \text { a. 火車 } & \text { b. 季節 } & \text { c. 時間 } \\ \text { 30.いま } & \text { a. 昨天 } & \text { b. 而今 } & \text { c. 今晚 } \\ \text { 31. はる } & \text { a. 春天 } & \text { b. 夏天 } & \text { c. 冬天 } \\ \text { 32. きれい } & \text { a. 冷 } & \text { b. 窗戶 } & \text { c. 美麗 } \\ \text { 33. きょねん } & \text { a. 去年 } & \text { b. 今年 } & \text { c. 明年 } \\ \text { 34. くちびる } & \text { a. 頭 } & \text { b. 嘴唇 } & \text { c. 臉煩 } \\ \text { 35. こわくて } & \text { a. 高興 } & \text { b. 舞動 } & \text { c. 害怕 } \\ \text { 36. おさない } & \text { a. 年幼 } & \text { b. 年老 } & \text { c. 壯年 } \\ \text { 37. おとな } & \text { a. 變得 } & \text { b. 發覺 } & \text { c. 長大 } \\ \text { 38. ホーム } & \text { a. 舞台 } & \text { b. 月台 } & \text { c. 大地 } \\ \text { 39. のこり } & \text { a. 留在 } & \text { b. 降落 } & \text { c. 離去 } \\ \text { 40. とける } & \text { a. 結冰 } & \text { b. 融化 } & \text { c. 貼著 }\end{array}$

\section{REFERENCES}

[1] Arnheim. R. (1974). Art and perception. Berkeley, CA: University of California Press.

[2] Arnheim, R. (1997). Visual thinking. Berkeley, California: University of California Press.

[3] Brett, P. (2001). Too many media in my multimedia? A study of the effects of combinations of media on a recall task. In: Escuela Superior de Administracion y Direccion de Empresas, Barcelona, Spain.

[4] Cassidy, G., \& MacDonald, R. (2007). The effect of background music and background noise on the task performance of introverts and extraverts. Psychology of Music, 35, 517-537.

[5] Cohen, J. (1988). Statistical power analysis for the behavioral sciences. Hillsdale, NJ: Erlbaum.

[6] Creswell, J. W. (2003). Research design: qualitative, quantitative and mixed methods approaches (2nd ed.). London: Sage Publications.

[7] Dondis, D.A. (1973). A primer of visual literacy. Cambridge, MA: MIT Press.

[8] Dwyer, F. M. (1978). Strategies for improving visual learning. State College, P.A.: Learning Services.

[9] Gombrich, E. H. (1972). Art and illusion: A study of the psychology of pictoria representation. Princeton, NJ: Princeton University Press.

[10] Gombrich, E. H. (1982). The image and the eye: Further studies in the psychology of pictorial representation. Ithaca, NY: Cornell University Press.

[11] Jentschke, S., Koelsch, S., \& Friederici, A. D. (2005). Investigating the relationship of music and language in children: Influences of musical training and language impairment. Annals of the New York Academy of Sciences, 1060, $231-242$.

[12] Jones, M. H., West, S. D., \& Estell, D. B. (2006). The Mozart effect: Arousal, preference, and spatial performance. Psychology of Aesthetics, Creativity, and the Arts, (1), 26-32.

[13] Kämpfe, J., Sedlmeier, P., \& Renkewitz, F. (2010). The impact of background music on adult listeners: A meta-analysis. Psychology of Music, 39(4), 424-448.

[14] Langer, S. (1957). Philosophy in a new key: A study in the symbolism of reason, rite and art. Cambridge, MA: Harvard University Press.

[15] Larsen-Freeman, D., \& Anderson, M. (2011). Techniques \& principles in language teaching (3rd ed.). Oxford: Oxford University Press.

[16] Legg, R. (2009). Using music to accelerate language learning: an experimental study. Research in Education, 82(1), 1-12.

[17] Messaris, P. (1994). Visual literacy: Image, mind, and reality. Boulder, CO: Waterview Press.

[18] Paivio, A. (1971). Imagery and verbal processes. New York: Rinehart and Winston Publishers.

[19] Paivio, A., \& Begg, I. (1981). Psychology of language. Englewood Cliffs, NJ: Prentice-Hall.

[20] Pallant, J. F. (2005). SPSS survival manual: a step by step guide to data analysis using SPSS. Sydney, Ligare.

[21] Patel, A. D. (2008). Music, language and the brain. Oxford: Oxford University Press.

[22] Sammler, D., Baird, A., Valabregue, R., Clement, S., Dupont, S., Belin, P., \& Samson, S. (2010). The relationship of lyrics and tunes in the processing of unfamiliar songs: An fMR adaptation study. Journal of Neuroscience, 10, 3572-3578.

[23] Schellenberg, E. G. (2006). Exposure to music: The truth about the consequences. In G. E. McPherson (Ed.), The child as musician: A handbook of musical development (pp. 111-134). Oxford, UK: Oxford University Press.

[24] Schellenberg, E. G. (2012). Cognitive performance after music listening: A review of the Mozart effect. In R. A. R. MacDonald G. Kreutz, \& L. Mitchell (Eds.), Music, health and wellbeing (pp. 324-338). Oxford, UK: Oxford University Press.

[25] Secret Base. (2001, August 8). Anime theme song [Video file]. Retrieved in January, 2018 at https://www.jpmarumaru.com/tw/JPSongPlay-1345.html

[26] Shanley, M. (1998). At the Mic: Karaoke Television. Compass Magazine, 5, 3. Retrieved in August, 2018 at http://www.taiwanfun.com/central/taichung/articles/9804/9804KTV.htm.

[27] Snowpack. (1974, March 12). Japanese folk song [Video file]. Retrieved in November, 2017 at https://www.jpmarumaru.com/tw/JPSongPlay-3391.html. 
[28] Thiessen, E. D., \& Saffran, J. R. (2009). How the melody facilitates the message and vice versa in infant learning and memory. The Neurosciences and Music III - Disorders and Plasticity: Annals of the New York Academy of Sciences, 1169, $225-233$.

[29] Wallace, W.T. (1994). Memory for music: Effect of melody on recall of text. Journal of Experimental Psychology: Learning, Memory, and Cognition, 20, 1471-1485. doi:10.1037/0278-7393.20.6.1471.

[30] Yule, G. (1985). The study of language: an introduction. Cambridge: Cambridge University Press.

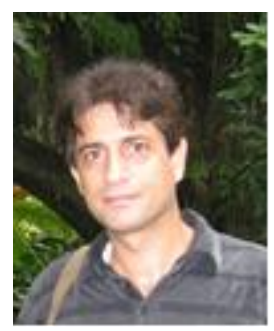

Abolfazl Shirban Sasi was born in Tehran, Iran, in 1970. He earned a Ph. D. degree in TESOL from Universiti Sains Malaysia (USM), Penang, Malaysia in 2012.

He currently teaches as a full-time assistant professor at the Department of Applied Foreign Languages (DAFL), TransWorld University, Taiwan. His research interests include: critical thinking in language classes, innovative techniques in TESOL/TEFL, language teacher training, syllabus design, language testing, etc.

Dr. Shirban Sasi has been a member of MELTA (Malaysian English Language Teaching Association); and the Inventors and Innovators Society of Iran. He has received two diplomas of honor from the Inventors and Innovators Society of Iran (2004 \& 2005); and an appreciation letter from the UNESCO Tehran Cluster Office (2005).

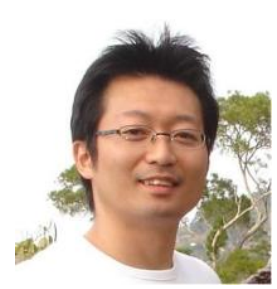

Toshinari Haga was born in Akita, Japan, in September 22, 1974. He received his Master's degree (Master of Business Administration in Marketing \& Sales) from Marylhurst University, Marylhurst, Oregon, U.S.A. in June 2000.

He was in an international trading business for 8 years accumulatively in Tokyo, Japan, Pforzheim, Germany and Taipei, Taiwan as a Sales Representative as well as Import \& Export Manager. He is currently a Full-time Lecturer at Department of Applied Foreign Language in TransWorld University, Yunlin, Taiwan since 2012.

Mr. Haga applies his extensive experience with multi-cultural and international business to his teaching from Entry Level to Advanced Level Japanese learners. 